\title{
The Risk of Cancer from CT Scans and Other Sources of Low-Dose Radiation: A Critical Appraisal of Methodologic Quality
}

\author{
Carl H. Schultz, MD; ${ }^{1}$ (1) Romeo Fairley, MD, MPH; ${ }^{2}$ Linda Suk-Ling Murphy, MLIS; ${ }^{3}$ \\ Mohan Doss, PhD, MCCPM ${ }^{4}$
}

1. Professor Emeritus of Emergency Medicine and Public Health, Department of Emergency Medicine, UCI School of Medicine, Irvine, California USA

2. Assistant Clinical Professor of Emergency Medicine, Department of Emergency Medicine, University of Texas Health School of Medicine, San Antonio, Texas USA

3. Research Librarian for Health Sciences, University of California, Irvine, California USA

4. Medical Physicist, Professor, Diagnostic Imaging, Fox Chase Cancer Center, Philadelphia, Pennsylvania USA

\section{Correspondence: \\ Carl H. Schultz, MD \\ Department of Emergency Medicine \\ Suite 640, Rt 128-01 \\ UC Irvine Medical Center \\ 333 The City Boulevard West \\ Orange California 92868 USA \\ E-mail: schultzc@uci.edu}

Conflicts of interest/funding: This project did not receive funding from any source. The authors have no conflicts of interest to declare.

Keywords: cancer risks; CT scans; disasters; methodology; radiation

\section{Abbreviations:}

BIER: Biological Effects of Ionizing Radiation

CT: computed tomography

Gy: Gray

LNT: linear-no-threshold

LSS: Life Span Study

mGy: milligray

$\mathrm{mSv}$ : millisievert

NOS: Newcastle Ottawa Scale

Sv: Sievert

Received: October 21, 2019

Accepted: October 30, 2019

\begin{abstract}
Introduction: Concern exists that radiation exposure from computerized tomography $(\mathrm{CT})$ will cause thousands of malignancies. Other experts share the same perspective regarding the risk from additional sources of low-dose ionizing radiation, such as the releases from Three Mile Island (1979; Pennsylvania USA) and Fukushima (2011; Okuma, Fukushima Prefecture, Japan) nuclear power plant disasters. If this premise is false, the fear of cancer leading patients and physicians to avoid CT scans and disaster responders to initiate forced evacuations is unfounded.
\end{abstract}

Study Objective: This investigation provides a quantitative evaluation of the methodologic quality of studies to determine the evidentiary strength supporting or refuting a causal relationship between low-dose radiation and cancer. It will assess the number of higher quality studies that support or question the role of low-dose radiation in oncogenesis.

Methods: This investigation is a systematic, methodologic review of articles published from 1975-2017 examining cancer risk from external low-dose x-ray and gamma radiation, defined as less than 200 millisievert (mSv). Following the PRISMA guidelines, the authors performed a search of the PubMed, Cochrane, Scopus, and Web of Science databases. Methodologies of selected articles were scored using the Newcastle Ottawa Scale (NOS) and a tool identifying 11 lower quality indicators. Manuscript methodologies were ranked as higher quality if they scored no lower than seven out of nine on the NOS and contained no more than two lower quality indicators. Investigators then characterized articles as supporting or not supporting a causal relationship between low-dose radiation and cancer.

Results: Investigators identified 4,382 articles for initial review. A total of 62 articles met all inclusion/exclusion criteria and were evaluated in this study. Quantitative evaluation of the manuscripts' methodologic strengths found 25 studies met higher quality criteria while 37 studies met lower quality criteria. Of the 25 studies with higher quality methods, 21 out of 25 did not support cancer induction by low-dose radiation $(\mathrm{P}=.0003)$.

Conclusions: A clear preponderance of articles with higher quality methods found no increased risk of cancer from low-dose radiation. The evidence suggests that exposure to multiple CT scans and other sources of low-dose radiation with a cumulative dose up to $100 \mathrm{mSv}$ (approximately 10 scans), and possibly as high as $200 \mathrm{mSv}$ (approximately 20 scans), does not increase cancer risk.

Schultz CH, Fairley R, Murphy LSL, Doss M. The risk of cancer from CT scans and other sources of low-dose radiation: a critical appraisal of methodologic quality. Prehosp Disaster Med. 2020;35(1):3-16.

\footnotetext{
Introduction

Background

There is little doubt that the advent of computerized tomography (CT) and other diagnostic radiologic imaging has revolutionized the practice of medicine; CT scans have

doi:10.1017/S1049023X1900520X

(C) The Author(s) 2020. This is an Open Access article, distributed under the terms of the Creative

Commons Attribution licence (http://creativecommons.org/licenses/by/4.0/), which permits

unrestricted re-use, distribution, and reproduction in any medium, provided the original work is properly cited.
} 


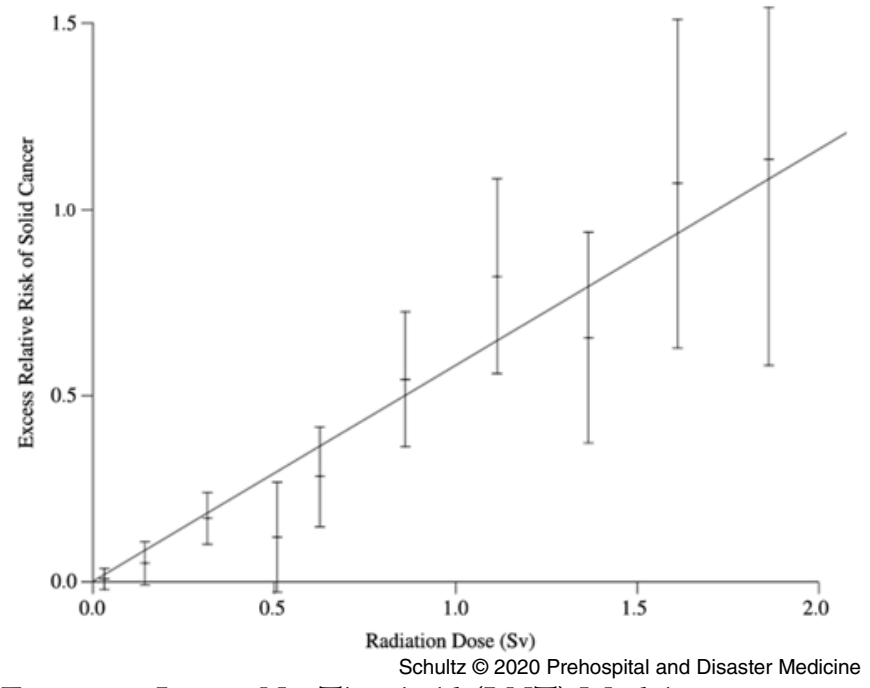

Figure 1. Linear-No-Threshold (LNT) Model.

Note: Relationship between increased cancer risk and radiation dose as reported by the "Health Risks from Exposure to Low Levels of Ionizing Radiation on: BEIR VII - Phase 2" report with $90 \%$ confidence bars. (Graph created by Stephen David Williams using the numbers reported in the BEIR report. Used with permission.)

essentially become ubiquitous in the United States, where approximately 74 million scans were performed in $2017 .{ }^{1}$ While this imaging technique offers benefits, the potential cancer risk associated with these studies remains controversial. If the wide-spread use of this technology is really inducing thousands of future cancer deaths, as suggested by Brenner, Berrington de Gonzalez, SmithBindman, and others, then the restrictive clinical guidelines being recommended by multiple organizations would be justified to protect the general population. ${ }^{2-4}$ However, if the risk is inaccurately represented, then the mandate to reduce CT scanning regardless of indication may not be rational. It is imperative that clinicians, as well as the public, understand the risks and benefits of diagnostic studies used in everyday practice. Therefore, an objective analysis of the evidence to date is necessary to evaluate the risk of cancer from CT scans.

To help understand the approach used in the following investigation, some background information is needed. For general purposes, when quantifying radiation exposure, the units of measure used are the Sievert (Sv) and Gray (Gy). The Sv quantifies the amount of damage done to the human body while the Gy is the energy absorbed in the body per unit mass. For both $\mathrm{x}$-rays and gamma rays, the two units of measure are numerically equivalent (ie, one Gy of radiation dose causes one Sv of damage). In addition, both gamma rays and $\mathrm{x}$-rays are thought to behave the same within human tissue, causing equivalent injury. Therefore, cancer studies involving either entity apply to both. The dose from a single CT scan ranges from two millisieverts $(\mathrm{mSv})$ to $20 \mathrm{mSv}$, with an average of two $\mathrm{mSv}$ per head $\mathrm{CT}$ and $10 \mathrm{mSv}$ per $\mathrm{CT}$ scan of the abdomen and pelvis. As a comparison, most Americans receive three $\mathrm{mSv}$ per year from natural background radiation sources. ${ }^{5}$

The most important study in estimating the cancer risk from radiation exposure is the continuous long-term follow-up investigation of Japanese survivors from the atomic bombs dropped on Hiroshima and Nagasaki in 1945. This longitudinal study is known as the Life Span Study, or LSS. In this Japanese population, cancer mortality and incidence have been studied as a function of radiation dose. Periodic reports on the data from this study are published by the Radiation Effects Research Foundation (Hiroshima, Japan). ${ }^{6}$ The health effects of radiation have been reviewed and published periodically by the Biological Effects of Ionizing Radiation Committee, or BEIR, of the National Academy of Sciences (Washington, DC USA), with the latest iteration of the report being BIER VII in 2006.

Since the first assessments of cancers in LSS participants, the analyses have reported a linear relationship between cancer incidence/mortality and increasing radiation dose when examining exposures of approximately one Gy and above. A report published in 2012 analyzing LSS data from 1950-2003 used a linear quadratic approach but asserts a similar overall relationship. ${ }^{8}$ However, a separate evaluation focused on the cancer risk at lower doses that did not rely on the linear model, especially at 200 milligray (mGy) and below, was not performed.

Due to the observed linear relationship at higher doses, and the potential for large errors in estimating excess cancer risk at low-doses, the authors of the serial BEIR Committee reports have extrapolated the observed linear relationship between radiation dose and excess cancers to apply to all doses. This approach has led to the linear-no-threshold (LNT) model relating cancer risk to exposure, illustrated in Figure 1. While this figure is derived from earlier data, it depicts the concept. The theory states that any amount of radiation increases cancer risk and no safe level of exposure exists. In other words, no threshold exists below which radiation exposure does not cause cancer. This concept of a linear relationship between cancer risk and radiation dose across all exposure levels has essentially been used for estimations of health risks from radiation for the last 60 years. Calculations of cancers caused by radiation exposure and safety limits for exposed populations were all derived from the LNT model.

\section{Importance}

For the first few decades after the model was proposed, little reason existed to challenge it. Only a minute segment of the population was at-risk for significant radiation exposure. All this changed with the invention of the CT scan in 1972, and the exponential rise in its utilization since. Now, very large segments of the population are receiving higher radiation exposures, and the potential risk of cancer in the dose range of $100-200 \mathrm{mSv}$ has become a very important issue. Recent publications have reached conflicting conclusions with respect to the cancer risk from low-dose exposure, resulting in intense debate regarding the validity of the LNT model. ${ }^{8,9}$ As such, the presence or absence of a threshold exposure limit for radiation-induced cancer has become a critical issue for the medical community and the public. Significant effort and progress have been made by the medical community to reduce radiation exposure, as documented by the National Council on Radiation Protection 160 (Bethesda, Maryland USA) and benchmarks such as the American College of Radiology's (Reston, Virginia USA) CT Dose Registry.

The latest analysis of the LSS data published by Grant, et al in 2017 only fuels the debate. Investigators demonstrated a threshold for cancer risk in men below $100 \mathrm{mGy} .{ }^{9}$ However, the authors were unable to make firm conclusions stating: "Findings from the current analysis regarding the dose-response shape were not fully consistent with those previously reported, raising unresolved 


\begin{tabular}{|l|}
\hline INCLUSION CRITERIA \\
\hline Adults and children \\
\hline Low-dose radiation defined as 200 mSv or less \\
\hline Studies published from 1975 through 2017 \\
\hline English language \\
\hline $\begin{array}{l}\text { Randomized controlled trials (and meta-analysis), cohort studies, case } \\
\text { control studies }\end{array}$ \\
\hline $\begin{array}{l}\text { External x-ray or gamma radiation exposure from diagnostic, } \\
\text { environmental (including atomic bomb Survivors), or occupational } \\
\text { sources }\end{array}$ \\
\hline $\begin{array}{l}\text { Studies where radiation exposure is either measured directly } \\
\text { or estimated using current equipment and accepted methods } \\
\text { where number and type of exposures are documented in a verifiable } \\
\text { dataset }\end{array}$ \\
\hline EXCLUSION CRITERIA \\
\hline Animal studies \\
\hline High-dose exposures, to include therapeutic radiation \\
\hline Prenatal and preconception exposures \\
\hline $\begin{array}{l}\text { Articles addressing radiation effects on cells (adaptive response and } \\
\text { bystander effects), chromosomes, biochemistry, or other non- } \\
\text { organism targets }\end{array}$ \\
\hline Review articles, abstracts, or editorials \\
\hline $\begin{array}{l}\text { Articles measuring calculated or estimated cancers based on modeling } \\
\text { of exposure risk }\end{array}$ \\
\hline Substantial exposure from internal contamination (excluding radon) \\
\hline Studies of patients with previous history of cancer \\
\hline $\begin{array}{l}\text { Studies examining radiation impact on other diseases besides } \\
\text { cancer such as meningiomas, cardiovascular disease, or mental } \\
\text { health }\end{array}$ \\
\hline $\begin{array}{l}\text { Studies using surveys/questionnaires, number of procedures } \\
\text { performed, or other indirect markers for actual radiation exposure }\end{array}$ \\
\hline
\end{tabular}

Table 1. Article Inclusion and Exclusion Criteria

questions. At this time, uncertainties in the shape of the dose response preclude definitive conclusions to confidently guide radiation protection policies. ${ }^{\prime 9}$ Nonetheless, the authors supported the use of a linear approach to data analysis consistent with the LNT model.

It is difficult to digest the large amount of data available and the conflicting conclusions stated in these publications. The authors considered using a meta-analytic approach for evaluating study outcomes but rejected it. All the investigations of human low-dose radiation exposure in the world's literature involve only cohort or case control studies. No prospective randomized trials exist. Cohort and case control studies are considered less robust designs, making meta-analysis of their results of questionable value. While some cohort and case control studies follow appropriate design rules, many are poorly constructed and highly flawed. As such, applying meta-analytic techniques to this mixture will yield results heavily confounded by lack of controls, poor study design, and flawed statistical evaluations. The resulting odds ratios and confidence intervals would have, at best, weak validity and at worst, be completely meaningless. In addition, the value of combining such studies is questionable. Given many involve different populations, outcome measures, sources of radiation, duration of exposure, sample size, and length of follow-up, the measurement of their heterogeneity would be very high, further compromising the validity of any findings.
It might be possible, however, to approximate an answer by identifying all the case control and cohort studies that more rigorously adhere to sound methodological design (utilize higher quality methodologies) and determine the number that either support or do not support the hypothesis that low-dose radiation causes cancer. A large preponderance of such investigations that endorse one or the other perspective would provide useful guidance.

\section{Study Objective}

Toward this end, the authors proposed examining the methodologic quality of investigations evaluating low-dose radiation and cancer induction published from 1975 through 2017. The articles' methodologies are scored using two separate tools to create a quantitative assessment measuring the strength of study design and identifying higher quality investigations. This will permit direct comparison between the number of studies using higher quality methodologies supporting cancer induction by low-dose radiation, and those refuting it, allowing assessment of the risks of cancer from low-dose radiation.

\section{Methods}

Study Design and Article Selection

Following the PRISMA guidelines, a systematic search was conducted in MEDLINE/PubMed (US National Library of Medicine, National Institutes of Health; Bethesda, Maryland USA); Scopus (Elsevier; Amsterdam, Netherlands; which includes coverage of EMBASE); Web of Science (Thomson Reuters; New York, New York USA); and the Cochrane Library (The Cochrane Collaboration; London, United Kingdom) for studies published in English from January 1975 through October 2017 evaluating the risk of cancer from low-dose radiation. The authors began the review in 1975 to allow sufficient time after the 1972 invention of the CT scan for research publications to appear that might include the device. A professional health sciences librarian (LM) designed and conducted the initial search on PubMed, and then applied the search strategy (Appendix A; available online only) to subsequent selected databases. All search results were imported into EndNote (Clarivate Analytics; Philadelphia, Pennsylvania USA), wherein duplicate studies were removed. For the search string, low-dose was defined as less than $200 \mathrm{mSv}$ for the purposes of article inclusion. The current definition of low-dose is up to $100 \mathrm{mSv}$; however, the authors wanted to ensure identification of all potential studies. ${ }^{10} \mathrm{In}$ addition, articles investigating lowdose radiation were not restricted to diagnostic medical devices. Analyses of low-dose gamma radiation, such as studies examining cancer rates in nuclear power industry workers or those exposed to elevated levels of background radiation, were included. Other publications from government and regulatory agencies were added as well, as those identified from selected article bibliography reviews conducted manually by the authors.

\section{Eligibility Criteria for Inclusion}

To be included in the study, articles had to address the potential role or impact of low-dose gamma or $\mathrm{x}$-ray radiation on the risk of developing any type of cancer. A list of article inclusion and exclusion criteria are contained in Table 1. First, two reviewers (CHS and RF) independently screened the titles and abstracts based on the criteria in Table 1. If this evaluation suggested the publications were potentially eligible for inclusion, the same reviewers examined the full-texts to make a final determination. 
If the two reviewers disagreed regarding study eligibility, differences of opinion were resolved by consensus. Any persistent disagreement was resolved by a third independent reviewer (MD). For datasets with multiple publications that serially evaluated the same population over time, only the most recent publication was considered for inclusion in the study.

\section{Measurements or Key Outcomes}

After identifying the final set of articles, the methodology of each paper was independently scored by two reviewers (CHS and RF) using two separate tools to determine the quality of the research approach. Reviewers used a scoring template to reduce inconsistency. The first tool is the Newcastle Ottawa Scale (NOS) initially created by George Wells, PhD. ${ }^{11}$ In an extensive review of approaches used for evaluation of non-randomized studies, 194 tools were identified that could be or had been used to assess such trials. Of these, only six were found to be suitable for systematic reviews, with the NOS being one. ${ }^{12}$ The NOS was chosen as it is specifically designed to evaluate the methodologies of cohort and case control studies, has been in use for over 15 years, and is frequently referenced in the emergency medicine literature. It scores articles on a range of zero to nine based on evaluations in three categories: (1) Selection of cases/controls or cohorts; (2) Comparability of case/controls or cohorts based on design; and (3) Exposure or Outcome (Appendix B; available online only). Articles with scores of seven or greater were considered higher quality, given that most authors using the NOS identify this number as the lower limit characterizing good studies. However, the NOS does not evaluate all methodological aspects. To capture potential weaknesses the NOS misses, a second tool is required to fully characterize the studies by examining data analysis. This tool was developed by the authors and adapted from established resources in research methodology (ie, statistics texts and review articles). It identifies 11 lower quality indicators that are used to score the studies. Examples of these indicators include use of 90\% confidence intervals, one-tailed $\mathrm{T}$ tests, failure to address confounding variables or predisposing factors, and no adjustment for multiple comparisons (Appendix C; available online only). An article found to contain two or fewer indicators is considered higher quality, mirroring the NOS that allows a reduction of up to two points for higher quality methodologies. An article's methodology was considered higher quality if: (1) it scored seven or more on the NOS, and (2) it contained two or fewer lower quality indicators. Failure to meet both metrics resulted in a study's methodology evaluated as lower quality. After independent scoring of all articles, both reviewers compared their results to reach consensus.

For meta-analytic studies, the NOS is not appropriate. To score these investigations, the authors used the Quality Assessment of Systematic Reviews and Meta-Analyses developed by the National Institute of Health's (Bethesda, Maryland USA) National Heart, Lung, and Blood Institute. This tool evaluates eight criteria as present or absent and yields a rating of good, fair, or poor. ${ }^{13}$ Articles containing a minimum of six criteria were considered higher quality, to maintain consistency with the other scoring tools. The lower quality indicator tool was applied to these studies without modification. Only one article required assessment using this tool.

\section{Data Analysis}

The articles were then divided into two groups: those supporting the risk of cancer from low-dose radiation, and those that did not. Investigators determined the support status by examining the conclusion section of the abstract, and when necessary, the conclusion section in the manuscript. The conclusion had to state or imply that all doses of radiation were associated with increased cancer risk. In some studies, the data reported in the results potentially contradicted the authors' conclusions. For the purposes of this investigation, however, the authors' statements were used to characterize the article. This same approach was used for studies that found an increase in some cancers but not others. Articles identified as not supporting the risk of cancer had to demonstrate a threshold for cancer induction at some level up to and including100-200 mSv, and that increased cancer rates were not observed or existed only above the threshold value. Finally, the number of higher quality articles supporting or not supporting cancer induction by low-dose radiation was counted, and the difference between the two groups was evaluated using a chi-squared test for independence (Stata, Statacorp; College Station, Texas USA) with a $\mathrm{P}$ value of less than .05 considered significant. Since the study involved only de-identified data, the research team was not required to obtain Institutional Review Board approval.

\section{Results}

\section{Characteristics of Selected Articles}

The literature search identified 4,382 potential articles for consideration: 4,361 retrieved from electronic databases and 21 obtained from bibliography reviews. After removal of duplicates, 3,578 publications remained. Initial screening of titles and abstracts reduced the number of articles further to 237. Detailed, independent full-text review of these remaining publications resulted in identification of 62 articles for inclusion in the study. Consensus was reached on all articles except one, which required intervention by a third author to adjudicate its disposition. A detailed graphic representation of the process following the PRISMA guidelines is listed in Figure 2.

\section{Main Results}

After evaluating and scoring the methodologic quality of all 62 articles, researchers identified 25 articles as utilizing higher quality approaches (Table $2^{9,14-37}$ ) and 37 characterized by lower quality approaches (Table $3^{38-74}$ ). These were fairly evenly divided with 27 articles endorsing cancer induction by low-dose radiation and 35 rejecting it. Examining the 25 higher quality methodology publications, the authors found 21 did not support the risk of cancer from low-dose radiation and four supported it. Using a chi-squared test for independence, this finding was significant with $\mathrm{P}=.0003$. The only publications to receive perfect scores on the two methodologic evaluations both did not support cancer risk. For investigations using lower quality methodologies, 23 supported cancer induction while 14 rejected it. Details of the scoring evaluation for each article are found in Appendix D (available online only).

\section{Discussion}

The initial possibility that radiation might increase mutations, and subsequently the risk of cancer, was raised by the work of $\mathrm{HJ}$ Muller, published in $1927 .{ }^{75}$ He demonstrated a linear increase in fruit fly mutations with exposure to rising doses of $\mathrm{x}$-rays, but used only high doses with the lowest dose being four Gy. A later study performed by Spencer during the Manhattan Project showed a similar linear relationship of mutations to radiation dose for short-duration exposures, but did not expose the fruit flies to low-dose radiation, stopping at a dose of $250 \mathrm{mGy} .{ }^{76}$ The influence 


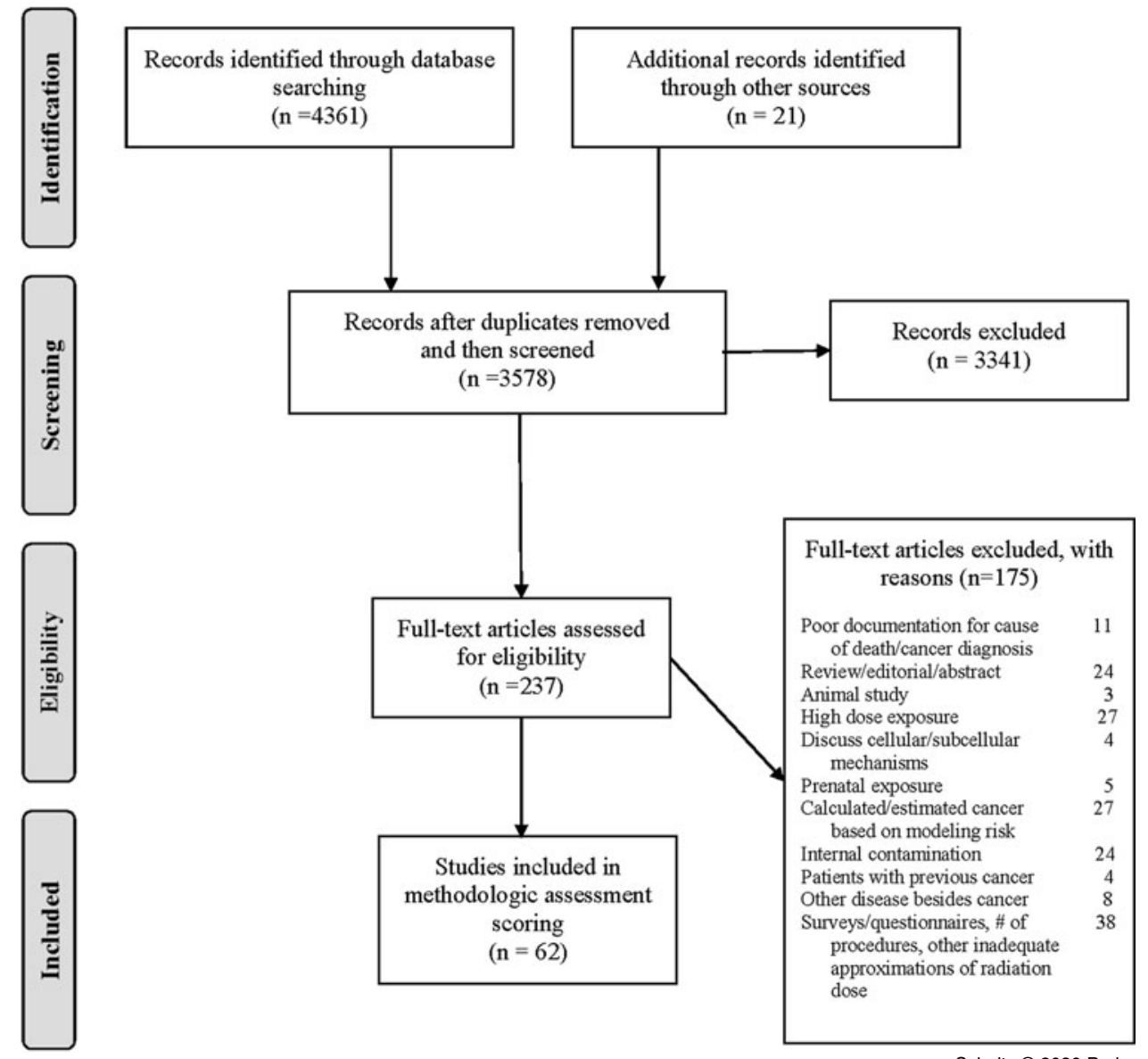

Figure 2. PRISMA Flow Diagram of Study Selection.

Schultz @ 2020 Prehospital and Disaster Medicine

Note: Chart depicting the process of reviewing and selecting eligible articles from literature search for subsequent methodologic scoring. (From: DOI: 10.1371/journal.pmed.1000097.)

of the Spencer investigation, in combination with the advocacy by Muller and others, resulted in the formal acceptance of the LNT model (all radiation causes cancer and the risk increases as a linear function of increasing radiation dose) by the National Academy of Sciences Genetics Panel on the Biological Effects of Atomic Radiation (BEAR I Committee, later to become the BEIR Committee) in $1956 .^{77}$

This linear model has remained the pivotal explanation for the relationship between radiation and cancer. The entire premise behind articles such as the one by Brenner, et al and others, that CT scans are causing cancer, is based on this model. ${ }^{2,3}$ If this model is false, however, his estimate that possibly as many as $1.5 \%$ to $2.0 \%$ of all cancers in the United States are caused by CT scans would be wrong. The purpose of this study was to examine the methodologic strengths of the literature and determine if the evidence from investigations using higher quality case control and cohort study methodologies supports or does not support the risk of cancer from low-dose radiation.

Researchers identified only four out of 25 studies characterized by higher quality methodologies that endorsed a risk of cancer from low-dose radiation. While no standard exists that can absolutely indicate when a sufficient quantity of higher quality studies has been performed to change practice, one can consider a change if the clear preponderance of these studies suggests a new direction is indicated. In this analysis, 21 out of 25 investigations characterized as using higher quality methodologies demonstrated the existence of a threshold for cancer induction. These studies demonstrated no increased cancer risk for individuals experiencing radiation exposures up to at least $100 \mathrm{mGy}$, and possibly as high as $200 \mathrm{mGy}$.

The authors acknowledge that attempting a quantitative analysis of methodologic quality will incorporate a certain amount of subjectivity. No tool currently available can completely eliminate this risk. However, significant guidance on use of the NOS exists, including structured scoring tools that can increase consistency in evaluations. These data collection sheets were employed throughout the entire evaluation (Appendix E; available online only). In addition, the use of the lower quality indicator tool to supplement the NOS provides a method of evaluation that is less subject to interpretation and more objective. This second evaluation tool is needed because the NOS does not evaluate how data are analyzed. Even if a study received a perfect score on the NOS, it can still have significant weaknesses in the way data are evaluated. Common errors such as use of $90 \%$ confidence intervals (CIs), failure to control for reverse causation, and failure to adjust for significant predisposing factors beyond the two that are addressed in the NOS all can result in lower quality methodologic approaches. These are the types of indicators used to create the second tool. 

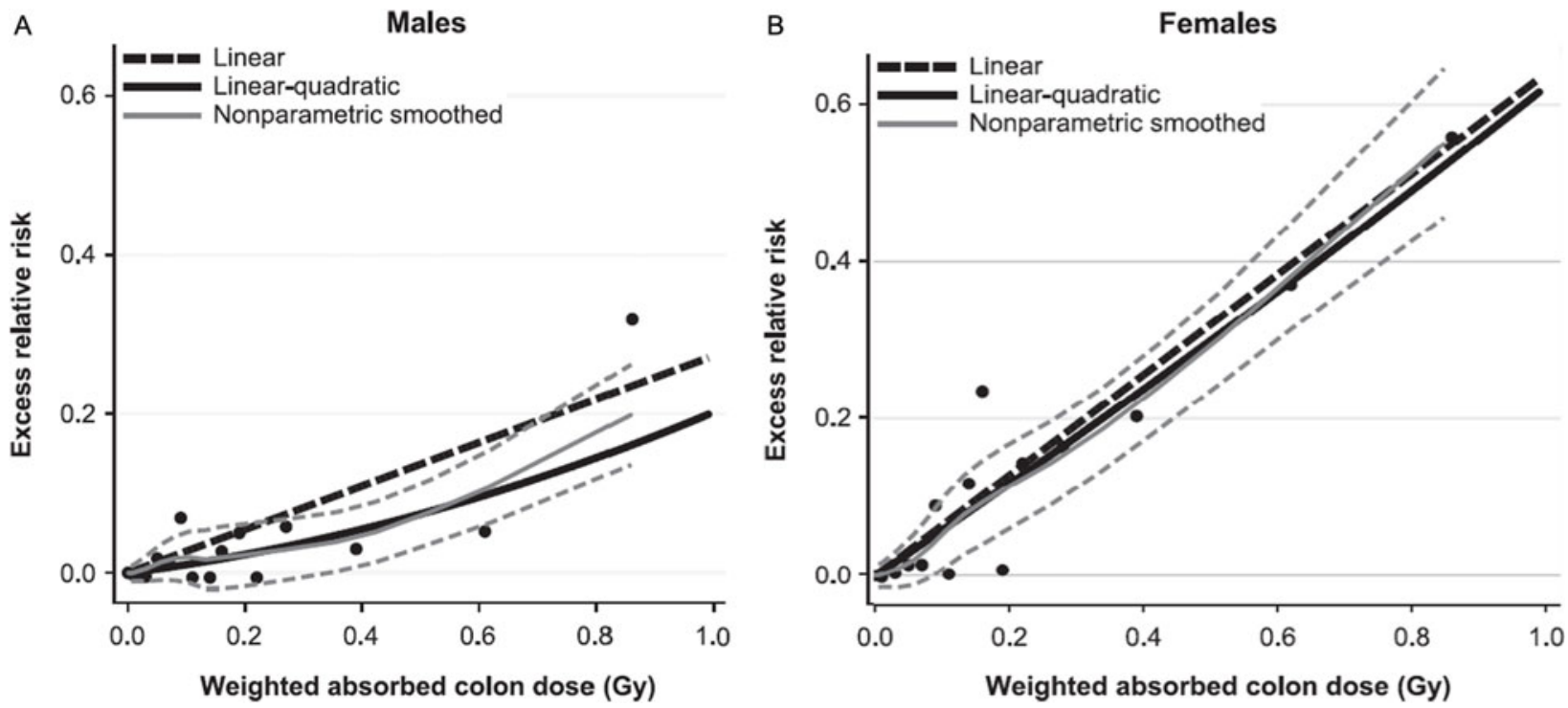

Figure 3. Cancer Risk for Males and Females as a Function of Increasing Radiation Exposure Up to $1 \mathrm{~Gy}$.

Note: Panels A and B: Solid cancer dose-response functions for males and females (0-1 Gy). Fitted linear (black dashed line) and linear-quadratic (black solid curve) ERRs for all solid cancers using linear and linear-quadratic dose-response functions for males and females over the range of $0-1 \mathrm{~Gy}$. Also shown are ERR estimates for 15 visible dose categories (points) and a nonparametric smoothed estimate (solid grey curve) with point-wise 95\% CIs (dashed grey curves). The ERRs are given for subjects at attained age of 70 years after exposure at age 30 years. (Used with permission; copyright 2018 Radiation Research Society).

To improve transparency, the individual scores for all articles are included in Appendix D (available online only), so readers can assess the study methodology evaluations for themselves.

Evaluation tools such as Grades of Recommendation, Assessment, Development, and Evaluation and others were not used for this study. They lack sufficient granularity to address the wide-range of study designs and subjects involved. As essentially none of the articles reviewed were randomized, controlled, prospective studies, they all would receive lower marks. This makes discrimination between cohort and case control studies using higher and lower quality methodologies difficult. Given all but one included article was either a case control or cohort study, investigators needed evaluations tools that would be effective in scoring these papers. That is why researchers selected the NOS and Lower Quality Indicator Scale.

The most widely cited data supporting the hypothesis that all radiation causes cancer comes from analysis of the LSS. While the data collected in this study are accurate, the linear and linear quadratic interpretation of the relationship between radiation and cancer across all levels of exposure is potentially flawed. In the latest examination of the LSS data by Grant, et al, a linear or curvilinear relationship does exist between increasing doses of radiation and an increased risk of cancer starting above $200 \mathrm{mGy} .{ }^{9}$ However, as one moves down the graphic line to lower doses of radiation below $200 \mathrm{mGy}$, a clear risk of increased cancer induction disappears. The graphs depicting the relationship between absorbed dose and cancer risk illustrate this observation (Figure 3). The dashed line illustrating the lower bounds of the $95 \%$ confidence interval for excess relative risk for cancer in men remains below zero until past $200 \mathrm{mGy}$, while that for women does not become positive until past $100 \mathrm{mGy} .{ }^{9}$ This fairly clearly suggests the possibility of a threshold for cancer risk if these data were evaluated as a separate entity rather than in totality with all the other data. Indeed, the conclusion of this latest LSS study shows no increased cancer risk in men for doses up to $100 \mathrm{mGy}$ (excess relative risk of 0.010 with $95 \%$ confidence intervals of -0.0003 to 0.021$).{ }^{9}$

It appears possible that two separate phenomena occur across the range of radiation exposure; one manifesting at low doses (100 mSv, possibly extending to $200 \mathrm{mSv}$ ) and a second process manifesting at higher doses. This is similar to the impact of sunlight on the human body. Low doses of ultraviolent radiation create vitamin D3 without causing significant skin damage. High doses will cause sunburn and increase the risk of skin cancer. Applying this concept, researchers would need a new objective model that could depict both processes while making no assumptions about the data. In fact, such models exist. Doss, et al used a regression approach in which the radiation dose in Gy was entered into the model using a restricted cubic spline transformation with four knots. This method of data analysis is flexible and allows the line of best fit to cross the $\mathrm{Y}$ axis at any location and also allows for negative predicted excess relative risk values. When this model is applied to the data from a previous analysis of the LSS, the $95 \%$ CIs for line of best fit are below zero for doses under $200 \mathrm{mGy}$, clearly demonstrating the possibility of a threshold. ${ }^{78}$

Sasaki, et al, concerned about the same issue of constrained data analysis, used a different approach. They employed an artificial neural network to examine the relationship between radiation dose and cancer risk. This method can identify changes in the dose-response relationship and is not limited to one type of graphical representation, allowing the line of best fit to follow the data. Using this model, the authors also identified a threshold effect, with no increased risk for radiation-induced cancer below $100-200 \mathrm{mSv}^{22}$

It might be useful to illustrate the difference found between studies using higher quality and lower quality methodologies by 
describing several investigations involving the risk of cancer from workplace radiation exposure from sources used to generate nuclear power. Studies concluding no cancer threshold exists suffer from significant flaws, including the use of spurious data, $90 \%$ confidence intervals, one-tailed tests of significance, and outcome measures that obscure the presence of a low-dose threshold, such as increased cancer risk per $\mathrm{Gy}$ or use of a restricted linear approach for data representation. ${ }^{43,44,55,79}$ Re-analysis of a study using information on occupational radiation exposure in the nuclear power industry from 15 countries that initially found a significant increase in cancer risk from low-dose exposure found no significantly increased risk after spurious Canadian data were excluded. ${ }^{21}$ In contrast, the Johns Hopkins School of Public Health (Baltimore, Maryland USA) conducted a study of cancer incidence in nuclear shipyard workers. This investigation was a rigorously performed search for health risks of radiation to civilian employees of eight shipyards that overhauled and repaired nuclear-propelled US Navy ships and submarines. They compared cancer rates experienced by badged nuclear workers servicing nuclear powered vessels who had exposure to low radiation doses with their colleagues who did not enter the radiation areas and so were not exposed to the low radiation doses. This eliminated any impact from the "healthy worker effect" (the phenomenon that employed individuals are healthier than the general population and so comparisons between the two can lead to inaccurate results). The authors used 95\% confidence intervals and non-linear restricted methods of data analysis, addressed such confounders as socio-economic status, and stratified worker analysis by radiation dose. These investigators found no increased risk of cancer from exposure to low-dose radiation. ${ }^{33}$

\section{Limitations}

Several limitations exist that potentially impact the study results. First, quantitative evaluation of methodologic quality incorporates a certain degree of subjectivity. Some criteria are difficult to objectively describe and so variability can occur in the quantification process. Investigators minimized this by using a scoring template that helped reduce inconsistency and by requiring consensus for each score. Second, the study authors performed the quantitative analysis. While it would be desirable to use another group blinded to the study's goal, it was not possible to find other emergency physicians that were unbiased. All the physicians contacted candidly admitted either a bias for or against the concept that all radiation causes cancer. None honestly believed that a state of equipoise could exist for either outcome. The authors were the only emergency physicians identified that believed that both outcomes were possible. Since scoring bias could not be completely eliminated, the raw scores for all 62 articles are included in the appendix so readers can assess the scoring accuracy for themselves. Third, some studies, if only modestly-powered, may have failed to identify a significant risk of cancer at lower doses due to the difference in the effect size. If there was a significant, but small, association between low-dose radiation and cancer, this might have required a larger sample to detect than associations at higher doses, reflecting a Type II error. However, this is unlikely as most studies included participants in the tens of thousands. In addition, the LSS just reported no evidence for cancer at doses below $100 \mathrm{mSv}$ in men, after reporting just the opposite for decades. This change reflects results from a now adequately powered study. Fourth, some studies may have yielded data that may not have easily fit within the binary outcomes of "support" or "not support." However, only three of the 62 articles produced mixed results, and none of these were in the higher quality study group. Even for these investigations, the authors' conclusions easily placed them into one of the two categories. Fifth, the authors analyzed studies documenting chronic exposure and acute intermittent exposure together. Very limited data exist quantifying the difference between cumulative low-dose exposure and single dose. Given the majority of studies evaluating both exposure types found no increased cancer rates, this is less likely to impact the results. Lastly, the lower quality indicator tool has not been used previously. Nonetheless, all 11 criteria are well-known, validated methodology flaws and are documented in research design textbooks and multiple review articles. It would seem difficult to argue that the results from studies with methods containing three or more of these known flaws could produce a meaningful evaluation.

\section{Conclusion}

This investigation demonstrates that a preponderance of studies using higher quality case control and cohort methodology support the existence of a threshold for cancer induction by radiation up to a dose of $100 \mathrm{mSv}$, and possibly as high as $200 \mathrm{mSv}$. These findings suggest that the cancer risk from this radiation dose is minimal and exposure to at least $10 \mathrm{CT}$ scans, and possibly as many as 20 , is unlikely to cause cancer.

\section{Author Contributions}

CHS, RF, and LS-LM are responsible for the conception and design of the study. LS-LM programmed the software to search the literature and provided data acquisition. Data analysis and interpretation was done by CHS, RF, and MD. Drafting and revision of the manuscript was performed by CHS, RF, LS-LM, and $\mathrm{MD}$ with all authors making substantial contributions. CHS takes responsibility for the manuscript content as a whole.

\section{Supplementary Material}

To view supplementary material for this article, please visit https:// doi.org/10.1017/S1049023X1900520X

\footnotetext{
References

1. IVM CT Products. 2017 CT Market Outlook Report. IMV website 2017. https:// imvinfo.com/product/2017-ct-market-outlook-report/. Accessed October 5, 2018.

2. Brenner DJ, Hall EJ. Computed tomography-an increasing source of radiation exposure. N Engl J Med. 2007;357(22):2277-2284.

3. Berrington de Gonzalez A, Mahesh M, Kim K-P, et al. Projected cancer risks from computed tomographic scans performed in the United States in 2007. Arch Intern Med. 2009;169(22):2071-2077.

4. Smith-Bindman R, Lipson J, Marcus R, et al. Radiation dose associated with common computed tomography examinations and the associated lifetime attributable risk of cancer. Arch Intern Med. 2009;169(22):2078-2086.

5. Mettler FA Jr, Huda W, Yoshizumi TT, et al. Effective doses in radiology and diagnostic nuclear medicine: a catalog. Radiology. 2008;248(1):254-263.
}

6. Life Span Study (LSS) Report Series. Radiation Effects Research Foundation website. https://www.rerf.or.jp/en/library/list-e/scientific_pub/1ss/. Accessed November 2, 2018.

7. National Research Council. Health Risks from Exposure to Low Levels of Ionizing Radiation: BEIR VII Phase 2. Vol. 7. Washington, DC USA: National Academies Press; 2006.

8. Ozasa K, Shimizu Y, Suyama A, et al. Studies of the mortality of atomic bomb survivors, report 14, 1950-2003: an overview of cancer and noncancer diseases. Radiat Res. 2012;177(3):229-243.

9. Grant EJ, Brenner A, Sugiyama H, et al. Solid cancer incidence among the Life Span Study of atomic bomb survivors: 1958-2009. Radiat Res. 2017;187(5): 513-537. 
10. United Nations Scientific Committee on the Effects of Atomic Radiation (UNSCEAR). Biological Mechanisms of Radiation Actions at Low Doses. UN: New York USA; 2012. http://www.unscear.org/docs/reports/Biological_ mechanisms_WP_12-57831.pdf. Accessed November 2, 2018.

11. Wells GA, Shea B, O'Connell D, et al. The Newcastle-Ottawa Scale (NOS) for assessing the quality of nonrandomized studies in meta-analyses. http://www.ohri. ca/programs/clinical_epidemiology/oxford.htm. Accessed October 22, 2018.

12. Deeks JJ, Dinnes J, D'Amico R, et al. Evaluating non-randomized intervention studies. Health Technol Assess. 2003;7(27).

13. National Heart, Lung, and Blood Institute. National Institutes of Health. Quality Assessment of Systematic Reviews and Meta-Analyses. https://www.nhlbi.nih.gov/ health-topics/study-quality-assessment-tools. Accessed October 11, 2018.

14. de Gonzalez AB, Salotti JA, McHugh K, et al. Relationship between pediatric CT scans and subsequent risk of leukemia and brain tumors: assessment of the impact of underlying conditions. Br J Cancer. 2016;114:388-394.

15. Huang WY, Muo CH, Lin CY, et al. Pediatric head CT scan and subsequent risk of malignancy and benign brain tumor: a nation-wide population-based cohort study. Br J Cancer. 2014;110:2354-2360.

16. Daniels RD, Bertke S, Waters KM, Schubauer-Berigan MK. Risk of leukemia mortality from exposure to ionizing radiation in US nuclear workers: a pooled casecontrol study. Occup Environ Med. 2013;70(1):41-48.

17. Kitahara CM, Linet MS, Balter S, et al. Occupational radiation exposure and deaths from malignant intracranial neoplasms of the brain and CNS in US radiologic technologists, 1983-2012. Am J Roentgenol. 2017;208:1278-1284.

18. Krille L, Dreger S, Schindel R, et al. Risk of cancer incidence before the age of 15 years after exposure to ionizing radiation from computed tomography: results from a German cohort study. Radiat Environ Biophys. 2015;54(1):1-12.

19. Journy N, Rehel J-L, Ducou Le Pointe H, et al. Are the studies on cancer risk from CT scans biased by indication? Elements of answer from a large-scale cohort study in France. Br J Cancer. 2015;112:185-193.

20. Socol Y, Dobrzyński L. Atomic bomb survivors' life-span study: insufficient statistical power to select radiation carcinogenesis model. Dose-Response. 2015;13(1):1.

21. Zablotska LB, Lane RSD, Thompson PA. A reanalysis of cancer mortality in Canadian nuclear workers (1956-1994) based on revised exposure and cohort data. Br J Cancer. 2014;110:214-223.

22. Sasaki MS, Tachibana A, Takeda S. Cancer risk at low doses of ionizing radiation: artificial neural networks inference from atomic bomb survivors. J Radiat Res. 2014;55(3):391-406.

23. Merzenich H, Hammer GP, Tröltzsch K, et al. Mortality risk in a historical cohort of nuclear power plant workers in Germany: results from a second follow-up. Radiat Environ Biophys. 2014;53(2):405-416.

24. Cappa M, Cambiaso P, Genovese E, et al. No thyroid abnormalities in patients submitted to cardiac catheterization in the first eighteen months of life. J Endocrinol Invest. 2013;36(1):7-11.

25. Tao Z, Akiba S, Zha Y, et al. Cancer and non-cancer mortality among inhabitants in the high background radiation area of Yangjiang, China (1979-1998). Health Phys. 2012;102(2):173-181.

26. Hammer GP, Blettner M, Langner I, Zeeb H. Cosmic radiation and mortality from cancer among male German airline pilots: extended cohort follow-up. Eur J Epidemiol. 2012;27(6):419-429.

27. Hammer GP, Seidenbusch MC, Regulla DF, et al. Childhood cancer risk from conventional radiographic examinations for selected referral criteria: results from a large cohort study. Am J Roentgenol. 2011;197(1):217-223.

28. Boice JD Jr, Cohen SS, Mumma MT, et al. Updated mortality analysis of radiation workers at Rocketdyne (Atomics International), 1948-2008. Radiat Res. 2011;176(2):244-258.

29. Jeong M, Jin Y-W, Yang KH, Ahn Y-O, Cha C-Y. Radiation exposure and cancer incidence in a cohort of nuclear power industry workers in the Republic of Korea, 1992-2005. Radiat Environ Biophys. 2010;49(1):47-55.

30. Nair RRK, Rajan B, Akiba S, et al. Background radiation and cancer incidence in Kerala, India-Karunagappally Cohort Study. Health Phys. 2009;96(1):55-66.

31. Gun RT, Parsons J, Crouch P, Ryan P, Hiller JE. Mortality and cancer incidence of Australian participants in the British nuclear tests in Australia. Occup Environ Med. 2008;65(12):843-848.

32. Yiin JH, Silver SR, Daniels RD, Zaebst DD, Seel EA, Kubale TL. A nested casecontrol study of lung cancer risk and ionizing radiation exposure at the Portsmouth Naval Shipyard. Radiat Res. 2007;168(3):341-348.

33. Sponsler R, Cameron JR. Nuclear shipyard worker study (1980-1988): a large cohort exposed to low-dose-rate gamma radiation. Int J Low Radiation. 2005;1;463-478.

34. Howe GR, Zablotska LB, Fix JJ, Egel J, Buchanan J. Analysis of the mortality experience amongst US nuclear power industry workers after chronic low-dose exposure to ionizing radiation. Radiat Res. 2004;162:517-526.

35. Inskip PD, Ekbom A, Galanti MR, Grimelius L, Boice JD Jr. Medical diagnostic x rays and thyroid cancer. J Natl Cancer Inst. 1995;87(21):1613-1621.
36. Boice JD Jr, Morin MM, Glass AG, et al. Diagnostic x-ray procedures and risk of leukemia, lymphoma, and multiple myeloma. JAMA. 1991;265(10):1290-1294.

37. Storme HH, Iversen E, Boice JD Jr. Breast cancer following multiple chest fluoroscopies among tuberculosis patients: a case-control study in Denmark. Acta Radiologica Oncology. 1986;25(4-6);233-238.

38. Daniels RD, Bertke SJ, Richardson DB, et al. Examining temporal effects on cancer risk in the international nuclear workers' study. Int J Cancer. 2017;140(6): 1260-1269.

39. Hsieh W-H, Lin I-F, Ho J-C, Chang PW. 30 years follow-up and increased risks of breast cancer and leukemia after long-term low-dose-rate radiation exposure. Br J Cancer. 2017;117:1883-1887.

40. Wang F, Sun Q, Wang J, Yu N. Risk of developing cancers due to low-dose radiation exposure among medical $\mathrm{x}$-ray workers in China-results of a prospective study. Int $\mathrm{J}$ Clin Exp Pathol. 2016;9:11897-11903.

41. Preston DL, Kitahara CM, Freedman DM, et al. Breast cancer risk and protracted low-to-moderate dose occupational radiation exposure in the US radiologic technologists' cohort, 1983-2008. Br J Cancer. 2016;115:1105-1112.

42. Smoll NR, Brady Z, Scurrah K, Mathews JD. Exposure to ionizing radiation and brain cancer incidence: the Life Span Study cohort. Cancer Epidemiol. 2016;42:60-65.

43. Richardson DB, Cardis E, Daniels RD, et al. Risk of cancer from occupational exposure to ionizing radiation: retrospective cohort study of workers in France, the United Kingdom, and the United States (INWORKS). BMJ. 2015;351:h5359.

44. Leuraud K, Richardson DB, Cardis E, et al. Ionizing radiation and risk of death from leukemia and lymphoma in radiation-monitored workers (INWORKS): an international cohort study. Lancet Haematol. 2015;2(7):e276-281.

45. Schubauer-Berigan MK, Daniels RD, Bertke SJ, Tseng C-Y, Richardson DB. Cancer mortality through 2005 among a pooled cohort of US nuclear workers exposed to external ionizing radiation. Radiat Res. 2015;183:620-631.

46. Mathews JD, Forsythe AV, Brady Z, Butler MW, Goergen SK, Byrnes GB. Cancer risk in 680,000 people exposed to computed tomography scans in childhood or adolescence: data linkage study of 11 million Australians. BMJ. 2013;346:f2360.

47. Samartzis D, Nishi N, Cologne J, et al. Ionizing radiation exposure and the development of soft-tissue sarcomas in atomic-bomb survivors. J Bone Joint Surg Am. 2013;95(3):222-229.

48. Choi K-H, Ha M, Lee WJ, et al. Cancer risk in diagnostic radiation workers in Korea from 1996-2002. Int J Environ Res Public Health. 2013;10:314-327.

49. Eisenberg MJ, Afilalo J, Lawler PR, Abrahamowicz M, Richard H, Pilote L. Cancer risk related to low-dose ionizing radiation from cardiac imaging in patients after acute myocardial infarction. CMAJ. 2011;183(4):430-436.

50. Ronckers CM, Land CE, Miller JS, Stovall M, Lonstein JE, Doody MM. Cancer mortality among women frequently exposed to radiographic exams for spinal disorders. Radiat Res. 2010;174(1):83-90.

51. Muirhead CR, O'Hagan JA, Haylock RGE, et al. Mortality and cancer incidence following occupational radiation exposure: third analysis of the National Registry for Radiation Workers. Br J Cancer. 2009;100:206-212.

52. Zielinski JM, Garner MJ, Band PR, et al. Health outcomes of low-dose ionizing radiation exposure among medical workers: a cohort study of the Canadian National Dose Registry of Radiation Workers. Int J Occup Med Environ Health. 2009;22(2):149-156.

53. Ronckers CM, Doody MM, Lonstein JE, Stovall M, Land CE. Multiple diagnostic $\mathrm{x}$-rays for spine deformities and risk of breast cancer. Cancer Epidemiol Biomarkers Prev. 2008;17(3):605-613.

54. Cardis E, Vrijheid M, Blettner M, et al. The 15-country collaborative study of cancer risk among radiation workers in the nuclear industry: estimates of radiation-related cancer risks. Radiat Res. 2007;167(4):396-416.

55. Cardis E, Vrijheid M, Blettner M, et al. Risk of cancer after low doses of ionizing radiation: retrospective cohort study in 15 countries. BMJ. 2005;331(7508):77-82.

56. Matsuura M, Hoshi M, Hayakawa N, et al. Analysis of cancer mortality among atomic bomb survivors registered at Hiroshima University. Int $J$ Radiat Biol. 1997;71(5):603-611.

57. Howe GR, McLaughlin J. Breast cancer mortality between 1950 and 1987 after exposure to fractionated moderate-dose-rate ionizing radiation in the Canadian fluoroscopy cohort study and a comparison with breast cancer mortality in the atomic bomb survivors' study. Radiat Res. 1996;145(6):694-707.

58. Cardis E, Gilbert ES, Carpenter L, et al. Effects of low doses and low dose rates of external ionizing radiation: cancer mortality among nuclear industry workers in three countries. Radiat Res. 1995;142(2):117-132.

59. Hoffman DA, Lonstein JE, Morin MM, et al. Breast cancer in women with scoliosis exposed to multiple diagnostic x rays. J Natl Cancer Inst. 1989;81(17): $1307-1312$

60. Jansen-van der Weide MC, Greuter MJW, Jansen L, Oosterwijk JC, Pijnappel RM, de Bock GH. Exposure to low-dose radiation and the risk of breast cancer among women with a familial or genetic predisposition: a meta-analysis. Eur Radiol. 2010;20(11):2547-2556. 
61. Ohira T, Takahashi H, Yasumura S, et al. Comparison of childhood thyroid cancer prevalence among 3 areas based on external radiation dose after the Fukushima Daiichi nuclear power plant accident: the Fukushima health management survey. Medicine. 2016;95(35):36.

62. Lee T, Sigurdson AJ, Preston DL, et al. Occupational ionizing radiation and risk of basal cell carcinoma in US radiologic technologists (1983-2005). Occup Environ Med. 2015;72(12):862-869.

63. White IK, Shaikh KA, Moore RJ, et al. Risk of radiation-induced malignancies from CT scanning in children who underwent shunt treatment before 6 years of age: a retrospective cohort study with a minimum 10-year follow-up. J Neurosurg Pediatr. 2014;13(5):514-519.

64. Metz-Flamant C, Laurent O, Samson E, et al. Mortality associated with chronic external radiation exposure in the French combined cohort of nuclear workers. Occup Environ Med. 2013;70(9):630-638.

65. Pogoda JM, Nichols PW, Ross RK, Stram DO, Thomas DC, Preston-Martin S. Diagnostic radiography and adult acute myeloid leukemia: an interview and medical chart review study. Br J Cancer. 2011;104:1482-1486.

66. Yuan M-K, Chien C-W, Lee S-K, et al. Health effects of medical radiation on cardiologists who perform cardiac catheterization. J Chin Med Assoc. 2010;73(4):199-204.

67. Vrijheid M, Elisabeth Cardis E, Ashmorec P, et al. Ionizing radiation and risk of chronic lymphocytic leukemia in the 15-country study of nuclear industry workers. Radiat Res. 2008;170(5):661-665.

68. Lambe M, Hall P, Granath F, Sadr Azodi O, Nilsson T. Coronary angioplasty and cancer risk: a population-based cohort study in Sweden. Cardiovasc Intervent Radiol. 2005;28(1):36-38.

69. Zielinski JM, Garner MJ, Krewski D, et al. Decreases in occupational exposure to ionizing radiation among Canadian dental workers. J Can Dent Assoc. 2005;71(1): 29-33.
70. Engels H, Swaen GMH, Slangen J, et al. Radiation exposure and cause specific mortality among nuclear workers in Belgium (1969-1994). Radiat Prot Dosimetry 2005;117(4):373-381.

71. Langner I, Blettner M, Gundestrup M, et al. Cosmic radiation and cancer mortality among airline pilots: results from a European cohort study (ESCAPE). Radiat Environ Biophys. 2004;42(4):247-256.

72. Iwasaki T, Murata M, Ohshima S, et al. Second analysis of mortality of nuclear industry workers in Japan, 1986-1997. Radiat Res. 2003;159(2): 228-238.

73. Artalejo FR, Lara SC, de Andres Manzano B, Ferruelo MG, Martin LI, del Rey Calero J. Occupational exposure to ionizing radiation and mortality among workers of the former Spanish Nuclear Energy Board. Occup Environ Med. 1997;54(3):202-208.

74. Jablon S, Boice JD Jr. Mortality among workers at a nuclear power plant in the United States. Cancer Causes Control. 1993;4(5):427-430.

75. Muller, HJ. Artificial transmutation of the gene. Science. 1927;66(1699):84-87.

76. Calabrese EJ. On the origins of the linear no-threshold (LNT) dogma by means of untruths, artful dodges and blind faith. Environmental Research. 2015;142: 432-442.

77. Committee on Genetic Effects of Atomic Radiation. Genetic effects of atomic radiation: Committee on Genetic Effects of Atomic Radiation. Science. 1956;123(3213):1157-1164.

78. Doss M, Egleston BL, Litwin S. Comments on studies of the mortality of atomic bomb survivors, report 14, 1950-2003: an overview of cancer and noncancer diseases. Radiat Res. 2012;178(3):244-245.

79. Preston DL, Mattsson A, Holmberg E, Shore R, Hildreth NG, Boice JD Jr. Radiation effects on breast cancer risk: a pooled analysis of eight cohorts. Radiat Res. 2002;158(2):220-235. 
ARTICLES SUPPORTING CANCER INDUCTION BY LOW-DOSE RADIATION

\begin{tabular}{|l|c|c|c|c|l|l|l|l|l|}
\hline Authors & Year & $\begin{array}{c}\text { Total NOS } \\
\text { Score }\end{array}$ & $\begin{array}{c}\text { Low-Quality } \\
\text { Indicator } \\
\text { Score }\end{array}$ & Sample Size & Study Design & Exposed Population & Radiation Source & Outcome Measures & $\begin{array}{l}\text { Follow-Up } \\
\text { Length }\end{array}$ \\
\hline Grant EJ, Brenner A & 2017 & 8 & 2 & 80,205 & Cohort & Atomic bomb survivors & Atomic bomb & Solid cancers \\
\hline $\begin{array}{l}\text { De Gonzalez AB, } \\
\text { Salotti JA }\end{array}$ & 2016 & 7 & 2 & 178,602 & Cohort & $\begin{array}{l}\text { Pediatric patients with } \\
\text { CT scans }\end{array}$ & CT scans & $\begin{array}{l}\text { Leukemia, malignant } \\
\text { brain lesion }\end{array}$ & 23 years \\
\hline $\begin{array}{l}\text { Huang WY, Muo } \\
\text { CH }^{15}\end{array}$ & 2014 & 8 & 2 & 24,418 & Cohort & $\begin{array}{l}\text { Pediatric patients with } \\
\text { head CTs }\end{array}$ & Head CT scans & $\begin{array}{l}\text { Malignant/benign brain } \\
\text { tumor }\end{array}$ & 10 years \\
$\begin{array}{l}\text { Daniels RD, } \\
\text { Bertke S }\end{array}$ & 2013 & 8 & 1 & 1,845 & $\begin{array}{l}\text { Nested case } \\
\text { control }\end{array}$ & US nuclear workers & $\begin{array}{l}\text { Radio-nuclides, nuclear } \\
\text { reactors }\end{array}$ & Leukemia mortality & 54 years \\
\hline
\end{tabular}

ARTICLES NOT SUPPORTING CANCER INDUCTION BY LOW-DOSE RADIATION

\begin{tabular}{|c|c|c|c|c|c|c|c|c|c|}
\hline Authors & Year & $\begin{array}{l}\text { Total NOS } \\
\text { Score }\end{array}$ & $\begin{array}{l}\text { Low-Quality } \\
\text { Indicator } \\
\text { Score }\end{array}$ & Sample Size & Study Design & Exposed Population & Radiation Source & Outcome Measures & $\begin{array}{l}\text { Follow-Up } \\
\text { Length }\end{array}$ \\
\hline $\begin{array}{l}\text { Kitahara CM, Linet } \\
\text { MS }^{17}\end{array}$ & 2017 & 8 & 2 & 110,297 & Cohort & $\begin{array}{l}\text { US radiologic } \\
\text { technologist }\end{array}$ & $\begin{array}{l}\text { Diagnostic medical } \\
\text { radiation }\end{array}$ & $\begin{array}{l}\text { Death from brain/CNS } \\
\text { cancer }\end{array}$ & 29 years \\
\hline Krille L, Dreger $\mathrm{S}^{18}$ & 2015 & 8 & 1 & 44,584 & Cohort & $\begin{array}{l}\text { Pediatric patients with } \\
\text { CT scans }\end{array}$ & CT scans & $\begin{array}{l}\text { Leukemia, lymphoma, } \\
\text { CNS tumor before age } \\
15\end{array}$ & 15 years \\
\hline $\begin{array}{l}\text { Journy N, } \\
\text { Rehel J-L }{ }^{19} \\
\end{array}$ & 2015 & 8 & 0 & 67,274 & Cohort & $\begin{array}{l}\text { Pediatric patients with } \\
\text { CT scans }\end{array}$ & CT scans & $\begin{array}{l}\text { Cancer incidence before } \\
\text { age } 15\end{array}$ & 10 years \\
\hline $\begin{array}{l}\text { Socol Y, } \\
\text { Dobrzyński L } 20\end{array}$ & 2015 & 8 & 1 & 86,661 & Cohort & Atomic bomb survivors & Atomic bomb & All cancer mortality & 53 years \\
\hline $\begin{array}{l}\text { Zablotska LB, Lane } \\
\text { RSD }^{21}\end{array}$ & 2014 & 7 & 1 & 45,468 & Cohort & $\begin{array}{l}\text { Canadian nuclear } \\
\text { workers }\end{array}$ & $\begin{array}{l}\text { Radio-nuclides, nuclear } \\
\text { reactors }\end{array}$ & All cancer mortality & 38 years \\
\hline $\begin{array}{l}\text { Sasaki MS, } \\
\text { Tachibana A }\end{array}$ & 2014 & 8 & 1 & 86,661 & Cohort & Atomic bomb survivors & Atomic bomb & $\begin{array}{l}\text { Occurrence of all } \\
\text { cancers }\end{array}$ & 50 years \\
\hline $\begin{array}{l}\text { Merzenich } \mathrm{H} \text {, } \\
\text { Hammer GP }\end{array}$ & 2014 & 8 & 1 & 8,972 & Cohort & $\begin{array}{l}\text { German nuclear power } \\
\text { workers }\end{array}$ & Nuclear power plants & All cancer mortality & 17 years \\
\hline $\begin{array}{l}\text { Cappa M, } \\
\text { Cambiaso } \mathrm{P}^{24}\end{array}$ & 2013 & 7 & 1 & 123 & Case control & $\begin{array}{l}\text { Patient }<18 \text { months old } \\
\text { with cardiac defects }\end{array}$ & $\begin{array}{l}\text { Cardiac } \\
\text { catheter-ization }\end{array}$ & $\begin{array}{l}\text { Thyroid abnormality and } \\
\text { cancer }\end{array}$ & 24 years \\
\hline Tao Z, Akiba S $\mathrm{S}^{25}$ & 2012 & 7 & 2 & 31,604 & Cohort & $\begin{array}{l}\text { Citizens living in } \\
\text { Yangjiang, China }\end{array}$ & $\begin{array}{l}\text { Natural background } \\
\text { radiation }\end{array}$ & $\begin{array}{l}\text { Cancer and } \\
\text { non-cancer deaths }\end{array}$ & 20 years \\
\hline $\begin{array}{l}\text { Hammer GP, } \\
\text { Blettner } \mathrm{M}^{26}\end{array}$ & 2012 & 7 & 1 & 6,000 & Cohort & $\begin{array}{l}\text { Male German airline } \\
\text { pilots }\end{array}$ & Cosmic radiation & Cancer mortality & 44 years \\
\hline $\begin{array}{l}\text { Hammer GP, } \\
\text { Seidenbusch } \mathrm{MC}^{27}\end{array}$ & 2011 & 9 & 0 & 78,527 & Cohort & $\begin{array}{l}\text { German children under } \\
\text { age } 14.5\end{array}$ & $\begin{array}{l}\text { Conventional radio- } \\
\text { graphic examination }\end{array}$ & Cancer incidence & 26 years \\
\hline Boice JD, Cohen $\mathrm{S}^{28}$ & 2011 & 9 & 2 & 46,970 & Cohort & Rocketdyne employees & Nuclear reactors \& fuel & Mortality analysis & 60 years \\
\hline Jeong $\mathrm{M}$, Jin $\mathrm{YW}^{29}$ & 2010 & 7 & 1 & 16,236 & Cohort & $\begin{array}{l}\text { Male Korean nuclear } \\
\text { power workers }\end{array}$ & Nuclear power facilities & Cancer incidence & 14 years \\
\hline
\end{tabular}




\begin{tabular}{|c|c|c|c|c|c|c|c|c|c|}
\hline Nair RRK, Rajan B ${ }^{30}$ & 2009 & 9 & 2 & 69,958 & Cohort & $\begin{array}{l}\text { People living in } \\
\text { Karunagappally, India }\end{array}$ & $\begin{array}{l}\text { Natural background } \\
\text { radiation }\end{array}$ & Cancer incidence & 15 years \\
\hline Gun RT, Parsons $\mathrm{J}^{31}$ & 2008 & 7 & 2 & 10,983 & Cohort & $\begin{array}{l}\text { Male Australian } \\
\text { participants in nuclear } \\
\text { tests }\end{array}$ & Nuclear weapons tests & $\begin{array}{l}\text { Mortality and cancer } \\
\text { incidence }\end{array}$ & 20 years \\
\hline $\begin{array}{l}\text { Sponsler R, } \\
\text { Cameron JR }\end{array}$ & 2005 & 9 & 0 & 70,730 & Cohort & $\begin{array}{l}\text { US Nuclear shipyard } \\
\text { workers }\end{array}$ & $\begin{array}{l}\text { Nuclear powered ships } \\
\text { and } x \text {-rays }\end{array}$ & $\begin{array}{l}\text { All-cause and cancer } \\
\text { mortality }\end{array}$ & 25 years \\
\hline $\begin{array}{l}\text { Howe GR, Zablotska } \\
\text { LB }^{34}\end{array}$ & 2004 & 9 & 1 & 53,698 & Cohort & $\begin{array}{l}\text { US nuclear power } \\
\text { workers }\end{array}$ & US nuclear power plants & $\begin{array}{l}\text { Non-cancer and cancer } \\
\text { mortality }\end{array}$ & 18 years \\
\hline $\begin{array}{l}\text { Boice JD Jr, } \\
\text { Morin } \mathrm{MM}^{36}\end{array}$ & 1991 & 7 & 2 & 2,481 & Case control & $\begin{array}{l}\text { US members of } 2 \\
\text { prepaid health plans }\end{array}$ & $\begin{array}{l}\text { Medical } x \text { - rays for } \\
\text { diagnosis }\end{array}$ & $\begin{array}{l}\text { Leukemia, NHL, multiple } \\
\text { myeloma }\end{array}$ & 27 years \\
\hline $\begin{array}{l}\text { Storm } \mathrm{HH}_{1} \\
\text { Iversen } \mathrm{E}^{37}\end{array}$ & 1986 & 7 & 2 & 479 & Case control & $\begin{array}{l}\text { Tuberculosis patients in } \\
\text { Denmark }\end{array}$ & Chest fluoroscopy & Breast cancer incidence & 40 years \\
\hline
\end{tabular}

Table 2. (continued). Articles with Higher Quality Methodologies Characterized by Supporting or Not Supporting Cancer Induction by Low-Dose Radiation Abbreviations: CNS, Central Nervous System; CT, Computed Tomography; NHL, Non-Hodgkin's Lymphoma; NOS, Newcastle Ottawa Scale; US, United States. 


\begin{tabular}{|c|c|c|c|c|c|c|c|c|c|}
\hline ARTICLES SUPPO & CANC & STION BY & DOSE RAD & & & & & & \\
\hline Authors & Year & $\begin{array}{l}\text { Total NOS } \\
\text { Score }\end{array}$ & $\begin{array}{l}\text { Low-Quality } \\
\text { Indicator } \\
\text { Score }\end{array}$ & Sample Size & \begin{tabular}{|l|} 
Study \\
Design
\end{tabular} & $\begin{array}{l}\text { Exposed } \\
\text { Population }\end{array}$ & Radiation Source & \begin{tabular}{|l|} 
Outcome \\
Measures
\end{tabular} & $\begin{array}{l}\text { Follow-Up } \\
\text { Length }\end{array}$ \\
\hline $\begin{array}{l}\text { Daniels RD, } \\
\text { Bertke SJ }{ }^{38}\end{array}$ & 2017 & 7 & 3 & 308,297 & $\begin{array}{l}\text { Nested } \\
\text { Case-Control }\end{array}$ & \begin{tabular}{|l|} 
Nuclear workers \\
(French, UK, US)
\end{tabular} & $\begin{array}{l}\text { Radio-nuclides, } \\
\text { gamma ray, x-ray, } \\
\text { neutron }\end{array}$ & $\begin{array}{l}\text { Mortality from } \\
\text { all solid } \\
\text { cancers, } \\
\text { leukemias } \\
\end{array}$ & $\begin{array}{l}\text { Average } \\
27 \text { years }\end{array}$ \\
\hline Hsieh WH, Lin $\mathrm{IF}^{39}$ & 2017 & 7 & 4 & 6242 & Cohort & $\begin{array}{l}\text { Taiwanese building } \\
\text { residents }\end{array}$ & $\begin{array}{l}\text { Cobalt-60 (gamma } \\
\text { ray) }\end{array}$ & All cancer & 30 years \\
\hline Wang F, Sun $Q^{40}$ & 2016 & 6 & 4 & 7703 & Case Control & $\begin{array}{l}\text { Chinese medical } \\
\text { x-ray workers }\end{array}$ & Medical x-ray & All cancer & \begin{tabular}{|l|}
315,309 \\
Person- years
\end{tabular} \\
\hline $\begin{array}{l}\text { Preston DL, } \\
\text { Kitahara } \mathrm{CM}^{41}\end{array}$ & 2016 & 8 & 3 & 66,915 & Cohort & $\begin{array}{l}\text { US radiologic } \\
\text { technologists }\end{array}$ & Medical x-ray & Breast cancer & \begin{tabular}{|l|}
$1,089,502$ \\
person- years
\end{tabular} \\
\hline Smoll NR, Brady $Z^{42}$ & 2016 & 8 & 4 & 105,427 & Cohort & $\begin{array}{l}\text { Atomic bomb } \\
\text { survivors }\end{array}$ & $\begin{array}{l}\text { Atomic bomb } \\
\text { radiation }\end{array}$ & Brain cancer & 40 years \\
\hline $\begin{array}{l}\text { Richardson DB, } \\
\text { Cardis } \mathrm{E}^{43}\end{array}$ & 2015 & 7 & 4 & 308,297 & Cohort & $\begin{array}{l}\text { Nuclear workers } \\
\text { (French, US, and } \\
\text { UK) }\end{array}$ & $\begin{array}{l}\text { Radio-nuclides, } \\
\text { gamma ray, x-ray, } \\
\text { neutron }\end{array}$ & $\begin{array}{l}\text { All cancer } \\
\text { mortality }\end{array}$ & \begin{tabular}{|l|}
8.2 million \\
person years, \\
median \\
26 years \\
\end{tabular} \\
\hline $\begin{array}{l}\text { Leuraud K, } \\
\text { Richardson DB }{ }^{44}\end{array}$ & 2015 & 7 & 3 & 308,297 & Cohort & $\begin{array}{l}\text { Nuclear workers } \\
\text { (French, US, and } \\
\text { UK) }\end{array}$ & $\begin{array}{l}\text { Radio-nuclides, } \\
\text { gamma ray, x-ray, } \\
\text { neutron }\end{array}$ & $\begin{array}{l}\text { Mortality from } \\
\text { leukemia and } \\
\text { lymphoma }\end{array}$ & \begin{tabular}{|l}
8.22 million \\
person-years
\end{tabular} \\
\hline $\begin{array}{l}\text { Schubauer-Berigan } \\
\text { MK, Daniels RD }{ }^{45}\end{array}$ & 2015 & 8 & 3 & 119,195 & Cohort & $\begin{array}{l}\text { Nuclear workers } \\
\text { (US) }\end{array}$ & $\begin{array}{l}\text { Radio-nuclides, } \\
\text { gamma ray, x-ray, } \\
\text { neutron }\end{array}$ & $\begin{array}{l}\text { All cancer } \\
\text { mortality }\end{array}$ & $\begin{array}{l}4,019,065 \\
\text { person-years }\end{array}$ \\
\hline $\begin{array}{l}\text { Mathews JD, } \\
\text { Forsythe AV }{ }^{46}\end{array}$ & 2013 & 6 & 2 & 680,211 & Cohort & $\begin{array}{l}\text { Australian Medicare } \\
\text { patients }\end{array}$ & CT imaging & All cancer & Mean 9.5 years \\
\hline $\begin{array}{l}\text { Samartzis D, } \\
\text { Nishi } \mathrm{N}^{47}\end{array}$ & 2013 & 8 & 3 & 80,180 & Cohort & $\begin{array}{l}\text { Atomic bomb } \\
\text { survivors }\end{array}$ & $\begin{array}{l}\text { Atomic bomb } \\
\text { radiation }\end{array}$ & $\begin{array}{l}\text { Soft tissue } \\
\text { sarcoma }\end{array}$ & \begin{tabular}{|l|}
$2,170,732$ \\
person-years
\end{tabular} \\
\hline Choi KH, Ha M ${ }^{48}$ & 2013 & 7 & 4 & 36,394 & Cohort & $\begin{array}{l}\text { Korean diagnostic } \\
\text { radiation workers }\end{array}$ & X-ray & All cancer & \begin{tabular}{|l} 
Max 7 years, \\
159,189 \\
person-years
\end{tabular} \\
\hline $\begin{array}{l}\text { Eisenberg MJ, } \\
\text { Afilalo } \mathrm{J}^{49}\end{array}$ & 2011 & 5 & 1 & 82,861 & Cohort & $\begin{array}{l}\text { Canadian cardiac } \\
\text { patients }\end{array}$ & X-ray & All cancer & Mean 5 years \\
\hline $\begin{array}{l}\text { Ronckers CM, } \\
\text { Land CE } 50\end{array}$ & 2010 & 8 & 4 & 5,513 & Cohort & US Scoliosis female & X-ray & $\begin{array}{l}\text { All cancer } \\
\text { mortality }\end{array}$ & $\begin{array}{l}\text { Mean } 47 \text { years, } \\
\text { total } 257,915 \\
\text { woman-years }\end{array}$ \\
\hline $\begin{array}{l}\text { Muirhead CR, } \\
\text { O'Hagan } \mathrm{JA}^{51}\end{array}$ & 2009 & 8 & 4 & 174,541 & Cohort & $\begin{array}{l}\text { UK Radiation } \\
\text { workers }\end{array}$ & $\begin{array}{l}\text { Radio-nuclides, } \\
\text { gamma ray, x-ray, } \\
\text { neutron }\end{array}$ & All cancer & $\begin{array}{l}3.9 \text { million } \\
\text { person-years }\end{array}$ \\
\hline $\begin{array}{l}\text { Zielinski JM, } \\
\text { Garner MJ } \mathrm{J}^{52}\end{array}$ & 2009 & 5 & 5 & 67,582 & Cohort & $\begin{array}{l}\text { Canadian medical } \\
\text { workers }\end{array}$ & Medical x-rays & $\begin{array}{l}\text { Cancer } \\
\text { mortality \& } \\
\text { incidence }\end{array}$ & 36 years \\
\hline $\begin{array}{l}\text { Ronckers CM, } \\
\text { Doody } \mathrm{MM}^{53}\end{array}$ & 2008 & 6 & 3 & 3,010 & Cohort & US scoliosis female & X-ray & Breast Cancer & $\begin{array}{l}118,905 \text { total } \\
\text { years, median } \\
35.5 \text { years }\end{array}$ \\
\hline
\end{tabular}




\begin{tabular}{|c|c|c|c|c|c|c|c|c|c|}
\hline $\begin{array}{l}\text { Cardis E, } \\
\text { Vrijheid } \mathrm{M}^{54}\end{array}$ & 2007 & 7 & 6 & 407,391 & Cohort & $\begin{array}{l}15 \text { country nuclear } \\
\text { workers }\end{array}$ & $\begin{array}{l}\text { Radio-nuclides, } \\
\text { gamma ray, x-ray, } \\
\text { neutron }\end{array}$ & $\begin{array}{l}\text { All cancer } \\
\text { mortality (cause } \\
\text { specific) }\end{array}$ & $\begin{array}{l}5.2 \text { million } \\
\text { person-years }\end{array}$ \\
\hline Cardis E, Vrijheid M ${ }^{55}$ & 2005 & 7 & 3 & 407,391 & Cohort & $\begin{array}{l}15 \text { country nuclear } \\
\text { workers }\end{array}$ & $\begin{array}{l}\text { Radio-nuclides, } \\
\text { gamma ray, x-ray, } \\
\text { neutron }\end{array}$ & $\begin{array}{l}\text { All cancer } \\
\text { mortality }\end{array}$ & $\begin{array}{l}5.2 \text { million } \\
\text { person-years }\end{array}$ \\
\hline $\begin{array}{l}\text { Matsuura M, } \\
\text { Hoshi M }{ }^{56}\end{array}$ & 1997 & 7 & 6 & 35,123 & Cohort & $\begin{array}{l}\text { Hiroshima } \\
\text { prefecture atomic } \\
\text { bomb survivors }\end{array}$ & $\begin{array}{l}\text { Atomic bomb } \\
\text { radiation }\end{array}$ & $\begin{array}{l}\text { All cancer } \\
\text { mortality }\end{array}$ & $\begin{array}{l}646,209 \\
\text { person-years }\end{array}$ \\
\hline $\begin{array}{l}\text { Howe GR, } \\
\text { McLaughlin } \mathrm{J}^{57}\end{array}$ & 1996 & 7 & 3 & 31,917 & Cohort & $\begin{array}{l}\text { Canadian } \\
\text { Tuberculosis }\end{array}$ & Fluoroscopy (x-ray) & $\begin{array}{l}\text { Breast cancer } \\
\text { mortality }\end{array}$ & Mean 31 years \\
\hline Cardis E, Gilbert ES ${ }^{58}$ & 1995 & 7 & 5 & 95,673 & Cohort & $\begin{array}{l}\text { Nuclear workers } \\
\text { (US, Canada, UK) }\end{array}$ & $\begin{array}{l}\text { Radio-nuclides, } \\
\text { gamma ray, x-ray, } \\
\text { neutron }\end{array}$ & $\begin{array}{l}\text { All cancer } \\
\text { mortality }\end{array}$ & $\begin{array}{l}2,124,526 \\
\text { person-years }\end{array}$ \\
\hline $\begin{array}{l}\text { Hoffman DA, } \\
\text { Lonstein JE }{ }^{59}\end{array}$ & 1989 & 6 & 5 & 1,030 & Cohort & $\begin{array}{l}\text { US scoliosis } \\
\text { patients }\end{array}$ & X-ray & Breast cancer & Mean 26 years \\
\hline
\end{tabular}

NIH Quality Assessment Score for Meta-Analyses

\begin{tabular}{|l|c|c|c|c|c|l|l|l|l|l|l}
$\begin{array}{l}\text { Jansen-Van Der } \\
\text { Weide, MC }\end{array}$ & 2010 & $\begin{array}{l}5 \text { out of } 8 \\
\text { possible criteria }\end{array}$ & 2 & $\begin{array}{l}\text { studies;30 to } \\
5865 \text { subjects }\end{array}$ & Meta-analysis & $\begin{array}{l}\text { Women with genetic } \\
\text { risk for breast } \\
\text { cancer }\end{array}$ & $\begin{array}{l}\text { Diagnostic medical } \\
\text { x-rays }\end{array}$ & $\begin{array}{l}\text { Breast cancer } \\
\text { Not stated to } \\
20 \text { years }\end{array}$ \\
\hline
\end{tabular}

\section{ARTICLES NOT SUPPORTING CANCER INDUCTION BY LOW-DOSE RADIATION}

\begin{tabular}{|c|c|c|c|c|c|c|c|c|c|}
\hline Authors & Year & $\begin{array}{l}\text { Total NOS } \\
\text { Score }\end{array}$ & $\begin{array}{l}\text { Low-Quality } \\
\text { Indicator } \\
\text { Score }\end{array}$ & Sample Size & Study Design & $\begin{array}{l}\text { Exposed } \\
\text { Population }\end{array}$ & Radiation Source & $\begin{array}{l}\text { Outcome } \\
\text { Measures }\end{array}$ & $\begin{array}{l}\text { Follow-Up } \\
\text { Length }\end{array}$ \\
\hline $\begin{array}{l}\text { Ohira T, } \\
\text { Takahashi } \mathrm{H}^{61}\end{array}$ & 2016 & 4 & 4 & 300,476 & Cross sectional & $\begin{array}{l}\text { Persons age } 0-18 \\
\text { living in Fukushima, } \\
\text { Japan }\end{array}$ & $\begin{array}{l}\text { External gamma } \\
\text { radiation }\end{array}$ & Thyroid cancer & 4 years \\
\hline Lee T, Sigurdson AJ ${ }^{62}$ & 2015 & 6 & 4 & 65,719 & Cohort & \begin{tabular}{|l|} 
US radiologic \\
technologists \\
\end{tabular} & $\begin{array}{l}\text { Diagnostic medical } \\
\text { x-rays }\end{array}$ & $\begin{array}{l}\text { Basal cell } \\
\text { carcinoma }\end{array}$ & 55 years \\
\hline White IK, Shaikh $\mathrm{KA}^{63}$ & 2014 & 6 & 1 & 104 & Cohort & \begin{tabular}{|l|} 
Children requiring \\
CSF shunts \\
\end{tabular} & Head CT scans & Any cancer & 10 years \\
\hline $\begin{array}{l}\text { Metz-Flamant C, } \\
\text { Laurent } \mathrm{O}^{64}\end{array}$ & 2013 & 8 & 5 & 59,021 & Cohort & $\begin{array}{l}\text { French nuclear } \\
\text { workers }\end{array}$ & $\begin{array}{l}\text { Neutrons, } x \text {-rays, } \\
\text { and gamma rays }\end{array}$ & $\begin{array}{l}\text { Any cancer, } \\
\text { stroke, or CAD }\end{array}$ & 36 years \\
\hline $\begin{array}{l}\text { Pogoda, JM, Nichols, } \\
\text { PW } \\
\end{array}$ & 2011 & 6 & 3 & 412 & Case control & $\begin{array}{l}\text { Adults living in Los } \\
\text { Angeles }\end{array}$ & $\begin{array}{l}\text { Diagnostic medical } \\
\text { x-rays }\end{array}$ & $\begin{array}{l}\text { Acute myeloid } \\
\text { leukemia }\end{array}$ & 7 years \\
\hline $\begin{array}{l}\text { Yuan, M-K, } \\
\text { Chien, C-W } 6\end{array}$ & 2010 & 3 & 3 & 2,292 & Case control & $\begin{array}{l}\text { Cardiologists in } \\
\text { Taipei, Taiwan }\end{array}$ & $\begin{array}{l}\text { Radiation from } \\
\text { fluoroscopy }\end{array}$ & $\begin{array}{l}\text { Cancer, } \\
\text { number of } \\
\text { medical visits, } \\
\text { cataracts, URIs } \\
\end{array}$ & 4 years \\
\hline $\begin{array}{l}\text { Vrijheid } \mathrm{M}, \\
\text { Cardis } \mathrm{E}^{67}\end{array}$ & 2008 & 6 & 2 & 295,963 & Cohort & $\begin{array}{l}\text { Nuclear workers in } \\
15 \text { countries }\end{array}$ & $\begin{array}{l}\text { X-rays and gamma } \\
\text { rays }\end{array}$ & $\begin{array}{l}\text { Chronic } \\
\text { lymphocytic } \\
\text { leukemia } \\
\text { deaths }\end{array}$ & $\begin{array}{l}4.5 \text { million } \\
\text { person-years; } \\
\text { 13-year } \\
\text { average }\end{array}$ \\
\hline
\end{tabular}




\begin{tabular}{|c|c|c|c|c|c|c|c|c|}
\hline Year & $\begin{array}{c}\text { Total NOS } \\
\text { Score }\end{array}$ & $\begin{array}{l}\text { Low-Quality } \\
\text { Indicator } \\
\text { Score }\end{array}$ & Sample Size & \begin{tabular}{|l|} 
Study \\
Design
\end{tabular} & $\begin{array}{l}\text { Exposed } \\
\text { Population }\end{array}$ & Radiation Source & \begin{tabular}{|l|} 
Outcome \\
Measures
\end{tabular} & $\begin{array}{l}\text { Follow-Up } \\
\text { Length }\end{array}$ \\
\hline 2005 & 5 & 2 & 42,175 & Cohort & $\begin{array}{l}\text { Canadian dental } \\
\text { workers }\end{array}$ & $\begin{array}{l}\text { Diagnostic dental X- } \\
\text { rays }\end{array}$ & $\begin{array}{l}\text { Cancer } \\
\text { mortality \& } \\
\text { incidence }\end{array}$ & 36 years \\
\hline 2003 & 6 & 1 & 176,000 & Cohort & $\begin{array}{l}\text { Male nuclear } \\
\text { workers in Japan }\end{array}$ & Gamma radiation & $\begin{array}{l}\text { All cause and } \\
\text { cancer mortality }\end{array}$ & 10 years \\
\hline 1997 & 6 & 1 & 5,657 & Cohort & $\begin{array}{l}\text { Spanish nuclear } \\
\text { workers and miners }\end{array}$ & Gamma radiation & $\begin{array}{l}\text { All cause and } \\
\text { cancer mortality }\end{array}$ & 38 years \\
\hline 1993 & 5 & 2 & 9,132 & Cohort & $\begin{array}{l}\text { Workers at a US } \\
\text { nuclear power plant }\end{array}$ & Gamma radiation & $\begin{array}{l}\text { All cause and } \\
\text { cancer mortality }\end{array}$ & 20 years \\
\hline
\end{tabular}

Table 3. (continued). Articles with Lower Quality Methodologies Characterized by Supporting or Not Supporting Cancer Induction by Low-Dose Radiation Abbreviations: CAD, Coronary Artery Disease; CSF, Cerebral Spinal Fluid; CT, Computed Tomography; NOS, Newcastle Ottawa Scale; PTCA, Percutaneous Transluminal Coronary Angioplasty; UK, United Kingdom; URI, Upper Respiratory Infection; US, United States. 